\title{
Cecal Enlargement and Microbial Flora in Suckling Mice Given Antibacterial Drugs
}

\author{
DWAYNE C. SAVAGE AND JULIA SUE MCALLISTER \\ Department of Microbiology, University of Texas, Austin, Texas 78712
}

Received for publication 28 September 1970

\begin{abstract}
Enlargement and microbial colonization of the cecum were examined in neonatal mice suckling mothers drinking either water or an aqueous solution of penicillin. The full ceca increased in weight at the same rate in both drug-treated and control mice during the first 15 to 17 days after birth. Thereafter, cecal weight increased at a greater rate in the drug-treated animals than in the untreated controls. At weaning, the ceca in treated mice were two to three times the size of control organs and remained enlarged as long as penicillin was given. The enlarged ceca did not differ histologically from those in controls. From birth, the cecal microflora in the drug-treated mice differed qualitatively and quantitatively and in colonization pattern from the flora of control mice. The ceca of untreated animals were colonized primarily by large populations of lactobacilli during the first week after birth, small populations of coliforms and enterococci during the second week, and enormous populations of bacteroides and certain gramnegative fusiform-shaped anaerobic bacteria during the third week. In contrast, the organs of the treated mice were populated by large populations of coliforms and enterococci during the first week and enormous populations of clostridia and unusual gram-negative nonsporeforming bacteria during the third week. These large abnormal populations were present in the ceca as they enlarged during the third week after birth in the drug-treated animals. These findings confirm that only certain populations of anaerobic bacteria can act to maintain cecal size in normal animals.
\end{abstract}

When adult mice are given solutions of certain antibacterial drugs for drinking water, their ceca fill with fluid and enlarge three to four times normal size within 12 to $18 \mathrm{hr}$ after the treatment is started (10). Depending upon the drug used, the enlarged ceca lose all or most of their indigenous microbial flora during the first 24 to $48 \mathrm{hr}$ but are colonized later by a microflora characteristic of the particular drug $(2,10)$. For that first 24 to $48 \mathrm{hr}$ of treatment, however, the ceca of these mice markedly resemble the enlarged ceca of germ-free rodents (10).

Germ-free rodents have large ceca, in part at least, because their ceca accumulate a substance that induces smooth muscles to relax (4). Apparently, this substance is synthesized continuously in the small bowel of all rodents but is inactivated in the cecum by the indigenous microflora in conventional animals (4).

Such a substance may induce the enlarged ceca of mice given antibacterial drugs. However, once the ceca of drug-treated mice enlarge, they remain large as long as the drug treat- ment is continued even though they are recolo. nized by enormous microbial populations (10). Presumably, such an extensive microbial flora would inactivate the substance able to induce muscle relaxation (4).

These considerations make necessary alternative, but not necessarily mutually exclusive, hypotheses to explain the enlarged ceca in drug-treated mice. One such alternative hypothesis is that some indigenous microorganisms may play an essential role in maintaining the integrity of the water-transport mechanism in the intestinal epithelium $(6,10)$. Water accumulates in the cecal lumen in mice given antibacterial drugs in their drinking water for the first 24 to $48 \mathrm{hr}$ of the treatment $(7,10)$. Indeed, during that period, the ceca increase in weight almost entirely because water collects in their lumens (10). The water may accumulate because normal water passage in and out of the ceca may be influenced in some way by the indigenous microbial flora $(6,10)$.

The microorganisms most likely to be involved in any such influence on cecal physiology are the 
anaerobic bacteria that predominate in the cecal microflora $(7,10)$. Particular anaerobic bacteria colonize the intestinal tracts of mice during the second to third week after birth $(11,13)$. If such bacteria are prevented from colonizing normally, ceca of baby mice should enlarge during that period.

We have tested this hypothesis in baby mice suckling mothers drinking penicillin solution. In this report, we show that the ceca do enlarge in such drug-treated neonates during the second or third week after birth. The enlarging ceca are colonized by large populations of microorganisms of various types including anaerobic bacteria. These findings and their implications are detailed in the following paragraphs.

\section{MATERIALS AND METHODS}

Mice. Swiss mice were obtained from the specific pathogen-free (SPF) NCS-D (8) colony maintained at the Rockefeller University (New York, N.Y.), the SPF $\mathrm{Ha}$ /ICR colony of A. R. Schmidt (Madison, Wis.), and the conventional colony of Euer's and Sons (Austin, Tex.).

Gravid females from the various colonies were maintained in individual cages with paper tops (Isocage, Bioquest) containing wood shavings for bedding. The females were given commercial pellets and acidified water (1). The date of birth of the young was carefully recorded so that the experiments could be conducted with animals of precisely known age.

Antibacterial drugs. Within $24 \mathrm{hr}$ after delivery of their young, mother mice were given aqueous solutions of penicillin for drinking water (see experiments).

Preparation of ceca for bacteriological examination. Animals were sacrificed under chloroform anesthesia and weighed. Their ceca, always with contents intact, were weighed and then homogenized in a Teflon grinder in $5 \mathrm{ml}$ of sterile charcoal-water (12).

Bacteriological culture techniques. The homogenates described above were diluted in charcoal-water in 10fold steps. Calibrated loopsful of each dilution were then spread on the surface of various selective agar media. The selective media and conditions of incubation used for the recovery and enumeration of lactobacilli, coliforms, enterococci, bacteroides, and clostridia have been described $(12,13)$. The method of estimating the populations of oxygen-intolerant anaerobes was developed from previously described systems (5). A vinyl chamber was modified from a standard vinyl isolator intended for housing germfree animals (Germ-free Equipment, Palatine, Ill.). Bacteriological work was carried out in this chamber after it had been exhausted by vacuum and refilled at least five times with deoxygenated nitrogen. After this treatment, methylene blue indicator remained colorless in the chamber for from 1 to 2 hours. The deoxygenated nitrogen was prepared by passing commercial oil-pumped nitrogen over heated copper in a gas purifying furnace (Sargent).
The bacteriological medium $\mathrm{O}$ and D (9) used for culturing oxygen-intolerant anaerobes was supplemented with 5\% human blood. We deoxygenated the medium prior to use in the chamber by incubating it for at least 3 days at $37 \mathrm{C}$ in an atmosphere of carbon dioxide and nitrogen (13). All media and other materials including dead mice were introduced into the chamber via an airlock that could be exhausted repeatedly by vacuum and refilled with deoxygenated nitrogen. The mice were killed with chloroform just prior to being put into the chamber. The bacteriological methods were carried out in the chamber as described $(5,12,13)$, except that charcoal-water was used only after it had been boiled and then incubated for at least 3 days at $37 \mathrm{C}$ in an atmosphere of $\mathrm{CO}_{2}$ and $\mathrm{N}_{2}$ (13). All media inoculated in the chamber were incubated in anaerobic jars in a $\mathbf{H}_{2-}$ $\mathrm{CO}_{2}$ atmosphere (GasPak, Bioquest).

Histological techniques. The ceca with contents intact were frozen in a $2 \%$ solution of methyl cellulose (15 centipoises) in $0.15 \mathrm{M}$ saline on the freezing shelf of a microtome-cryostat (International Equipment Co., Needham Heights, Mass.). Sections of the frozen tissues were cut at either 4 or $8 \mu \mathrm{m}$, fixed for $60 \mathrm{sec}$ in absolute methyl alcohol, and stained with hematoxylin and eosin or a modified tissue Gram stain (11).

\section{RESULTS}

Body weights of neonatal mice suckling mothers drinking penicillin solution. On the day of delivery of their young, mother mice from the SPF NCS-D and $\mathrm{Ha} / \mathrm{ICR}$ and the conventional Euer's colonies were given penicillin solution $(0.3 \mathrm{~g} / \mathrm{liter})$ to drink. The drug treatment was continued from that time until 5 weeks after delivery. The penicillin solution was renewed daily. At intervals after birth, babies from the treated group and from a control group drinking acidified water were killed and weighed. Their ceca were then removed and either weighed, cultured for bacterial flora, or examined histologically as is described in subsequent sections.

The penicillin in the maternal drinking water did not affect appreciably the gain in body weight of the NCS-D and the Ha/ICR neonates from birth to weaning (Table 1). In contrast, the Euer's neonates suckling mothers drinking penicillin solution gained weight scmewhat more rapidly than their control counterparts. However, in both the treated and control groups, Euer's mice grew more slowly and attained lower weaning weights than did animals from the two SPF colonies. Such observations are made frequently when similar experiments are carried out with mice from colonies housed conventionally (3).

Cecal weights in neonatal mice suckling mothers drinking penicillin solution. In some of the experiments described above, weights were made of ceca removed with contents intact at intervals 


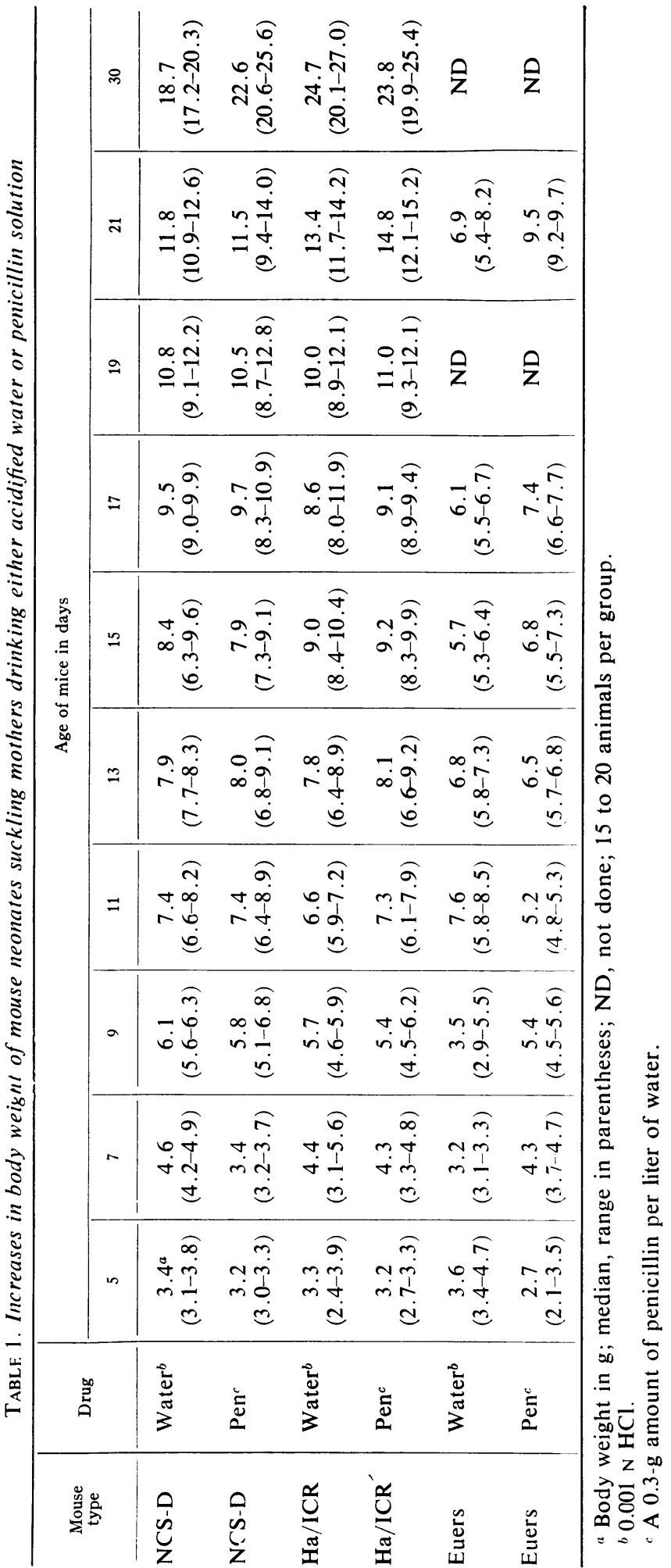


TABLE 2. Increases in cecum weight in mouse neonates suckling mothers drinking either acidified water or penicillin solution

\begin{tabular}{|c|c|c|c|c|c|c|c|c|c|c|c|}
\hline \multirow{2}{*}{ Mouse type } & \multirow{2}{*}{ Drug } & \multicolumn{10}{|c|}{ Age of mice in days } \\
\hline & & 5 & 7 & 9 & 11 & 13 & 15 & 17 & 19 & 21 & 30 \\
\hline NCS-D & Water $^{b}$ & $\begin{array}{c}5^{a} \\
(2-9)\end{array}$ & $\begin{array}{c}12 \\
(9-15)\end{array}$ & $\begin{array}{c}13 \\
(11-19)\end{array}$ & $\begin{array}{c}15 \\
(11-20)\end{array}$ & $\begin{array}{c}24 \\
(19-29)\end{array}$ & $\begin{array}{c}34 \\
(30-39)\end{array}$ & $\begin{array}{c}40 \\
(31-43)\end{array}$ & $\begin{array}{c}130 \\
(101-185)\end{array}$ & $\begin{array}{c}167 \\
(101-190)\end{array}$ & $\begin{array}{c}380 \\
(325-435)\end{array}$ \\
\hline NCS-D & $\operatorname{Pen}^{c}$ & $\begin{array}{c}5 \\
(3-7)\end{array}$ & $\begin{array}{c}11 \\
(9-13)\end{array}$ & $\begin{array}{c}17 \\
(14-18)\end{array}$ & $\begin{array}{c}33 \\
(25-50)\end{array}$ & $\begin{array}{c}52 \\
(39-70)\end{array}$ & $\begin{array}{c}58 \\
(51-60)\end{array}$ & $\begin{array}{c}91 \\
(82-100)\end{array}$ & $\begin{array}{c}158 \\
(110-235)\end{array}$ & $\begin{array}{c}367 \\
(252-435)\end{array}$ & $\begin{array}{c}850 \\
(681-944)\end{array}$ \\
\hline $\mathrm{Ha} / \mathbf{I C R}$ & Water $^{b}$ & $\begin{array}{l}4 \\
(3-5)\end{array}$ & $\begin{array}{c}6 \\
(4-9)\end{array}$ & $\begin{array}{c}9 \\
(7-11)\end{array}$ & $\begin{array}{c}14 \\
(11-17)\end{array}$ & $\begin{array}{c}25 \\
(21-29)\end{array}$ & $\begin{array}{c}30 \\
(18-37)\end{array}$ & $\begin{array}{c}41 \\
(32-67)\end{array}$ & $\begin{array}{c}143 \\
(112-160)\end{array}$ & $\begin{array}{c}199 \\
(144-229)\end{array}$ & $\begin{array}{c}369 \\
(321-435)\end{array}$ \\
\hline $\mathrm{Ha} / \mathrm{ICR}$ & $\operatorname{Pen}^{c}$ & $\begin{array}{c}4 \\
(2-5)\end{array}$ & $\begin{array}{c}5 \\
(4-8)\end{array}$ & $\begin{array}{c}10 \\
(8-14)\end{array}$ & $\begin{array}{c}11 \\
(10-14)\end{array}$ & $\begin{array}{c}21 \\
(12-28)\end{array}$ & $\begin{array}{c}33 \\
(22-37)\end{array}$ & $\begin{array}{c}50 \\
(46-81)\end{array}$ & $\begin{array}{c}242 \\
(202-361)\end{array}$ & $\begin{array}{c}315 \\
(255-331)\end{array}$ & $\begin{array}{c}1042 \\
(850-1190)\end{array}$ \\
\hline Euers & Water $^{b}$ & $\begin{array}{c}5 \\
(2-8)\end{array}$ & $\begin{array}{c}3 \\
(2-5)\end{array}$ & $\begin{array}{c}5 \\
(2-9)\end{array}$ & $\begin{array}{c}16 \\
(13-18)\end{array}$ & $\begin{array}{c}18 \\
(17-31)\end{array}$ & $\begin{array}{c}18 \\
(12-24)\end{array}$ & $\begin{array}{c}30 \\
(23-34)\end{array}$ & ND & $\begin{array}{c}108 \\
(78-143)\end{array}$ & ND \\
\hline Euers & $\operatorname{Pen}^{c}$ & $\begin{array}{c}3 \\
(2-4)\end{array}$ & $\begin{array}{c}5 \\
(4-5)\end{array}$ & $\begin{array}{c}5 \\
(4-12)\end{array}$ & $\begin{array}{l}13 \\
(7-16)\end{array}$ & $\begin{array}{c}27 \\
(12-38)\end{array}$ & $\begin{array}{c}20 \\
(20-29)\end{array}$ & $\begin{array}{c}45 \\
(28-49)\end{array}$ & ND & $\begin{array}{c}247 \\
(232-262)\end{array}$ & ND \\
\hline
\end{tabular}

${ }^{a}$ Cecum weight in mg; median, range in parentheses; ND, not done; 15 to 20 animals per group.

${ }^{b} 0.001 \mathrm{~N} \mathrm{HCl}$.

${ }^{c}$ A 0.3-g amount of penicillin per liter of water.

after birth from neonates suckling mothers drinking either the penicillin solution $(0.3 \mathrm{~g} / \mathrm{liter})$ or acidified water (Table 2). The full ceca enlarged at approximately the same rate in the control and treated babies in the $\mathrm{Ha} / \mathrm{ICR}$ and Euer's groups for the first $\mathbf{1 5}$ to $\mathbf{1 7}$ days. Thereafter, in those mice cecum size increased most rapidly in babies suckling mothers drinking penicillin solution. In fact, the ceca enlarged much more rapidly in the treated than in the control animals; by 30 days after birth the organs of the drugtreated animals were two to three times the size of the control ceca. The NCS-D babies suckling mothers given penicillin were somewhat an exception to this general pattern; in these mice the full ceca began to increase in size at greater than control rates at about 11 to 13 days after birth. In other respects, however, the enlargement process in the NCS-D neonates was identical to that seen in the other types of mice.

Colonization by aerobic and microaerophilic bacteria of the ceca of neonatal mice. Cultures for aerobic, facultatively aerobic, and microaerophilic bacteria were made from some of the ceca removed at various intervals after birth from the neonatal mice suckling mothers drinking either acidified water or penicillin solution (Table 3). Only mice from the two SPF colonies were used in these experiments. The Euer's mice were omitted because they were conventional animals with typically complex pcpulations of indigenous microorganisms (12).

The bacteria able to grow aerobically or microaerophilically colonized the ceca of the control babies from both SPF colonies in much the same fashion as has been reported for NCS and NCS-D mice $(11,13)$. Populations of lactobacilli appeared soon after birth and rose to the high levels characteristic of adults within the first week after birth. Populations of coliforms and enterococci appeared in the second week after birth, increased quickly to substantial levels, and then declined somewhat to the lower levels characteristic of adults during the third week after birth.

In contrast, these facultative and microaerophilic bacteria colonized the ceca of the drugtreated babies in quite a different pattern. Lactobacilli could not be cultured at any time after birth from the neonates suckling mothers drinking penicillin. Strikingly, however, populations of coliforms and to some extent enterococci established within the first week after birth increased quickly to quite high levels and remained at those levels into adulthood. Such high population levels of coliforms and enterococci are seen also in adult mice given penicillin solution to drink $(2,10)$.

Colonization by anaerobic bacteria of the ceca of neonatal mice. Cultures for anaerobic bacteria were also made from some of the ceca removed from the neonatal mice (Table 4). Anaerobes tolerant of oxygen were grown in an atmosphere of $\mathrm{CO}_{2}$ and $\mathrm{N}_{2}$ (11) on $-\mathrm{S}$ medium (13) inoculated in the air. Such organisms were cultured from both NCS-D and Ha/ICR neonates. Anaerobes intolerant of oxygen were grown in an $\mathrm{H}_{2}-\mathrm{CO}_{2}$ (Gas Pak) atmosphere on deoxygenated 
TABLE 3. Colonization by aerobic and microaerophilic bacteria of the ceca of NCS-D and Ha/ICR mouse neonates suckling mothers drinking either acidified water or penicillin solution ${ }^{a}$

\begin{tabular}{|c|c|c|c|c|c|c|c|c|c|c|c|c|}
\hline \multirow{2}{*}{ Mice } & \multirow{2}{*}{ Drug } & \multirow{2}{*}{ Bacteria } & \multicolumn{10}{|c|}{ Age of mice in days } \\
\hline & & & 5 & 7 & 9 & 11 & 13 & 15 & 17 & 19 & 21 & 30 \\
\hline NCS-D & Water ${ }^{b}$ & Lactobacillie & 4 & 9 & 9 & 9 & 9 & 9 & 9 & 9 & 9 & 9 \\
\hline NCS-D & Water & Coliforms $^{c}$ & $\mathbf{N}$ & $\mathrm{N}$ & $\mathrm{N}$ & \pm & 6 & 6 & 5 & 4 & 4 & 4 \\
\hline NCS-D & Water & Enterococci & $\mathbf{N}$ & $\mathrm{N}$ & \pm & 6 & 7 & 6 & 4 & 4 & 4 & 4 \\
\hline NCS-D & $\operatorname{Pen}^{d}$ & Lactobacillic & $\mathbf{N}$ & $\mathrm{N}$ & $\mathrm{N}$ & $\mathrm{N}$ & $\mathrm{N}$ & $\mathrm{N}$ & $\mathrm{N}$ & $\mathrm{N}$ & $\mathrm{N}$ & $\mathrm{N}$ \\
\hline NCS-D & Pen & Coliforms $^{c}$ & $\mathrm{~N}$ & 6 & 9 & 9 & 9 & 10 & 10 & 10 & 10 & 10 \\
\hline NCS-D & Pen & Enterococci & $\mathbf{N}$ & $N$ & $\mathbf{N}$ & 9 & 10 & 10 & 10 & 10 & 10 & 10 \\
\hline $\mathrm{Ha} / \mathrm{ICR}$ & Water & Lactobacilli & 4 & 8 & 8 & 8 & 8 & 8 & 8 & 8 & 8 & 8 \\
\hline $\mathrm{Ha} / \mathrm{ICR}$ & Water & Coliforms ${ }^{c}$ & \pm & \pm & \pm & \pm & 4 & 4 & 4 & 6 & 4 & 4 \\
\hline $\mathrm{Ha} / \mathrm{ICR}$ & Water & Enterococci & \pm & \pm & $\mathbf{N}$ & 4 & 4 & 6 & 6 & 4 & 4 & 4 \\
\hline $\mathrm{Ha} / \mathrm{ICR}$ & Pen & Lactobacilli & $\mathrm{N}$ & $\mathrm{N}$ & $\mathrm{N}$ & $\mathrm{N}$ & $\mathrm{N}$ & $\mathrm{N}$ & $\mathrm{N}$ & $\mathrm{N}$ & $\mathrm{N}$ & $\mathrm{N}$ \\
\hline $\mathrm{Ha} / \mathrm{ICR}$ & Pen & Coliforms $^{c}$ & 7 & 7 & 9 & 10 & 10 & 10 & 10 & 10 & 10 & 10 \\
\hline $\mathrm{Ha} / \mathrm{ICR}$ & Pen & Enterococci & $\mathbf{N}$ & \pm & 4 & 8 & 7 & 9 & 9 & 10 & 9 & 9 \\
\hline
\end{tabular}

${ }^{a}$ The data are recorded as the average of the $\log _{10}$ of the numbers of bacteria per gram of fresh tissue; 15 to 20 animals per group. The \pm indicates bacteria infrequently cultured in low numbers; $N$, no bacteria recovered.

${ }^{b} 0.001 \mathrm{~N} \mathrm{HCl}$.

$c$ The coliforms are predominantly slow fermenters of lactose (SLF) in untreated NCS-D and rapid lactose fermenters in untreated $\mathrm{Ha} / \mathrm{ICR}$ mice. In penicillin-treated animals of both mouse strains the coliforms are either Klebsiella sp. or rapid lactose fermenters that form mucoid colonies.

${ }^{d}$ A $0.3-\mathrm{g}$ amount of penicillin per liter of water.

- In NCS-D mice the designation lactobacilli includes anaerobic streptococci (Gr.N) as well as $L a c$ tobacillus $\mathrm{sp}$.

$\mathrm{O}$ and $\mathrm{D}$ medium (9) supplemented with $5 \%$ human blood and inoculated in an atmosphere of deoxygenated $\mathrm{N}_{2}$. Cultures for these oxygenintolerant bacteria were made only from $\mathrm{Ha} / \mathrm{ICR}$ infants.

The anaerobes tolerant of oxygen and able to grow on $-\mathrm{S}$ medium colonized the ceca of the control babies from both mouse colonies in a pattern essentially identical to that previously reported for NCS and NCS-D mice $(11,13)$. These bacteria are mostly bacteroides; they colonize the infant cecum at the end of the second week after birth and quickly establish high population levels characteristic of the adult.

Penicillin treatment delayed somewhat the colonization of the cecum by oxygen-tolerant anaerobes but did not reduce the final population levels of such bacteria. In fact, penicillin-treated $\mathrm{Ha} / \mathrm{ICR}$ babies yielded from their ceca higher population levels of these anaerobes than did untreated babies. More importantly, however, the populations of such bacteria in these drugtreated animals consisted mostly of clostridia rather than bacteroides. Therefore, similarly to its effect on the facultative and microaerophilic flora, penicillin induced marked changes in the quality of this particular fraction of the anaerobic flora.

The fraction of the anaerobic microflora that is intolerant of oxygen was cultured on $\mathrm{O}$ and $\mathrm{D}$ medium supplemented with human blood. This medium is not selective for particular types of intestinal bacteria. Consequently, when incubated anaerobically, it will support the growth of facultatively anaerobic as well as strictly anaerobic bacteria. Therefore, this medium must be inoculated with cecal homogenates both in the air and in a desxygenated $\mathrm{N}_{2}$ atmosphere and then incubated anaerobically. This procedure permits more accurate estimates to be made of the 
TABLE 4. Colonization by anaerobic bacteria of the ceca of NCS-D and Ha/ICR mouse neonates suckling mothers drinking either acidified water or penicillin solution ${ }^{a}$

\begin{tabular}{|c|c|c|c|c|c|c|c|c|c|c|c|c|c|}
\hline \multirow{2}{*}{ Mice } & \multirow{2}{*}{$\begin{array}{c}\text { Types of } \\
\text { anaerobes }^{b}\end{array}$} & \multirow{2}{*}{ Medium } & \multirow{2}{*}{ Drug } & \multicolumn{10}{|c|}{ Age of mice in days } \\
\hline & & & & 5 & 7 & 9 & 11 & 13 & 15 & $1 i$ & 19 & 21 & 30 \\
\hline NCS-D & $\mathrm{O}_{2}=$ & $-S$ & Water ${ }^{c}$ & $\mathbf{N}$ & $\mathbf{N}$ & $\mathbf{N}$ & \pm & 8 & 8 & 10 & 10 & 10 & 10 \\
\hline NCS-D & tolerant & $-\mathbf{S}$ & $\operatorname{Pen}^{d}$ & $\mathbf{N}$ & $\mathbf{N}$ & $\mathbf{N}$ & $\mathbf{N}$ & $\mathbf{N}$ & $\mathbf{N}$ & 4 & 10 & 10 & 10 \\
\hline $\mathrm{Ha} / \mathrm{ICR}$ & $\mathrm{O}_{2}=$ & $-\mathrm{S}$ & Water ${ }^{c}$ & $\mathbf{N}$ & $\mathbf{N}$ & $\mathrm{N}$ & $\mathbf{N}$ & \pm & 8 & 8 & 8 & 8 & 8 \\
\hline $\mathrm{Ha} / \mathrm{ICR}$ & intolerant & $-S$ & $\operatorname{Pen}^{d}$ & $\mathbf{N}$ & $\mathbf{N}$ & $\mathbf{N}$ & $\mathbf{N}$ & \pm & \pm & 4 & 10 & 10 & 10 \\
\hline $\mathrm{Ha} / \mathrm{ICR}$ & $\mathrm{O}_{2}=$ & $O$ and $D$ & Water ${ }^{c}$ & \pm & 7 & 6 & ND & 8 & 9 & 8 & ND & 8 & 8 \\
\hline $\mathrm{Ha} / \mathrm{ICR}$ & tolerant & $O$ and $D$ & $\operatorname{Pen}^{d}$ & 7 & 7 & 7 & 8 & 9 & 9 & 9 & ND & 10 & 10 \\
\hline $\mathrm{Ha} / \mathrm{ICR}$ & $\mathrm{O}_{2}=$ & $O$ and $\mathrm{D}$ & Water ${ }^{c}$ & 7 & 8 & 9 & 9 & 9 & 10 & 11 & ND & 10 & 10 \\
\hline $\mathrm{Ha} / \mathrm{ICR}$ & intolerant & $O$ and $D$ & $\operatorname{Pen}^{d}$ & 7 & 7 & 7 & 8 & 8 & 10 & 10 & ND & 10 & 10 \\
\hline
\end{tabular}

${ }^{a}$ Data recorded as the average of the $\log _{10}$ of the numbers of bacteria per gram of fresh tissue; \pm , bacteria infrequently cultured in low numbers; ND, not done; 15 to 20 animals per group.

${ }^{b}$ Anaerobes tolerant of oxygen are cultured in an atmosphere of $\mathrm{CO}_{2}$ and $\mathrm{N}_{2}$ on media inoculated in the air. Under these conditions bacteroides are the most numerous organisms cultured on $-\mathrm{S}$ medium (13) from untreated mice of both colonies. In contrast, such cultures yield clostridia almost exclusively from mice treated with penicillin. Anaerobes intolerant of oxygen will grow in an $\mathrm{H}_{2}-\mathrm{CO}_{2}(\mathrm{GasPak})$ atmosphere on prereduced media inoculated in an atmosphere of deoxygenated nitrogen (5). Under these conditions, fusiform-shaped and spiral-shaped microorganisms (5) from very high dilutions of sample material and lactobacilli, coliforms, and bacteroides from lower dilutions can be cultured from untreated animals on $\mathrm{O}$ and $\mathrm{D}$ medium.

c $0.001 \mathrm{~N} \mathrm{HCl}$.

${ }^{d}$ A $0.3-g$ amount of penicillin per liter of water.
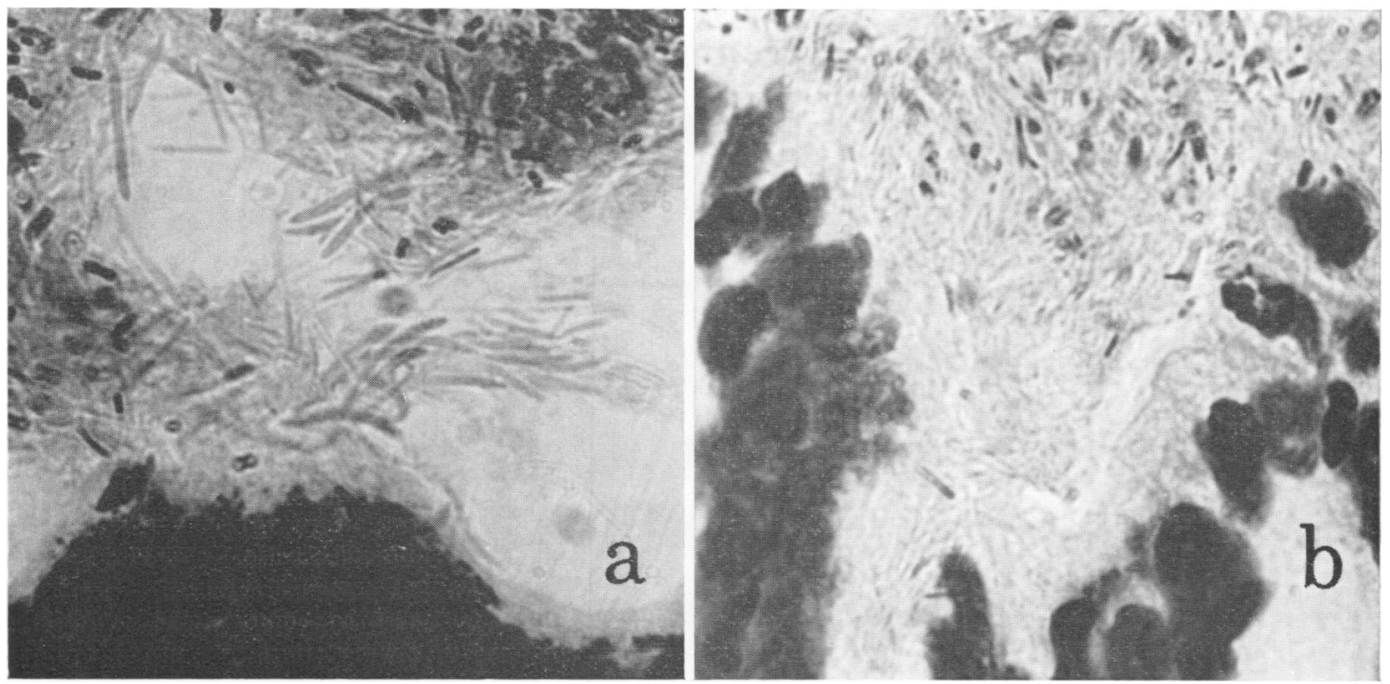

FIG. 1. Gram-stained histological sections of the ceca of 17-day-old Ha/ICR mice suckling mothers drinking either: (a) acidified water $(0.001 \times \mathrm{HCl})$ or $(b)$ aqueous penicillin solution $(0.3 \mathrm{~g} /$ liter $)$. Sections show mucosal epithelium at the bottom, mucous layers on the epithelium, and mixed microbial populations at the top. Fusi-

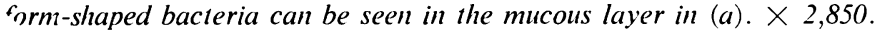

populations of oxygen-intolerant anaerobes. The estimates made from counts of colonies grown on plates inoculated in air can be subtracted from the estimates made from counts of cclonies grown on plates inoculated in $\mathbf{N}_{2}$ (Table 4).
The results of this manipulation show that populations of oxygen-intolerant anaerobes predominate over other bacterial populations in untreated babies over 13 days of age. The manipulation does not permit, however, the same con- 
clusion for treated infants. In these animals, counts of coliforms and oxygen-tolerant anaerobes are much the same as the counts of oxygenintolerant anaerobes. Moreover, similar types of microorganisms, i.e., clostridia and long, thin gram-negative rods, grow on the $\mathbf{O}$ and $\mathrm{D}$ media inoculated either in the air or in deoxygenated $\mathrm{N}_{2}$ with cecal material from treated animals. In contrast, in untreated mice the oxygen-intolerant populations consist predominantly of fusiformshaped bacteria. Consequently, the anaerobic populations in the treated mice, though enormous, differ considerably from the analogous population in untreated animals.

Histology of the cecal microflora in neonatal mice. Frozen-section histological preparations were made of many of the ceca removed from the neonatal mice suckling mothers drinking either acidified water or penicillin solution (Fig. $1)$. The sections shown are from ceca of 17 day-old mice. At this time populations of anaerobic bacteria predominate in the ceca of both the treated and untreated mice. However, as indicated by culture results fusiform-shaped bacteria predominate in the lumen and on the mucosal epithelium in the sections of the ceca removed from the control babies. In contrast, coccal-shaped gram-positive and long, thin, rod-shaped, gram-negative microorganisms predominate in the sections of the organs from treated mice. Importantly, these microorganisms do not populate in layers the epithelial mucin as do certain fusiform-shaped bacteria in untreated animals. These histological findings confirm the culture findings; i.e., the predominating types of microbial species in the cecal microflora of treated animals differ markedly from those in the flora of untreated mice.

\section{DISCUSSION}

In this study we show that baby mice suckling mothers drinking penicillin solution experience cecal enlargement during the second or third week after birth. Depending upon the type of mice tested, this period coincides with or follows immediately after the time when strictly anaerobic microorganisms colonize the large bowel in normal untreated mice $(11,13)$. Thus, the ceca enlarge only during or after this anaerobic microbial flora is disrupted in the penicillin-treated mice. This timing may be only coincidental, however; the treated animals may experience cecal enlargement during the second or third week after birth only because at that time they take in more penicillin than they had previously. Neonatal mice begin to sample water and solid food during the second to third week after birth (personal observation). Consequently, the treated babies may take in more penicillin by drinking the drug solution than they receive from their mothers' milk. Thus, the ceca may enlarge at two to three weeks of age in the treated babies because only at that time is sufficient penicillin present in their guts to be effective in altering the flora.

There is no doubt, however, that at the dosage levels used sufficient penicillin passes through the mother's milk to disrupt considerably the microbial flora from birth onwards. Lactobacilli colonize during the first week after birth in untreated mice but never colonize at all in the treated animals. In contrast, coliforms colonize and reach high populations during the first week in the treated mice but not until the second week in untreated controls. These alterations in the microflora during the first week do not lead to immediate enlargement of the ceca, however; such enlargement begins to take place only at the end of the second week. Consequently, cecal enlargement in the drug-treated babies is not due simply to alteration of the facultatively aerobic and microaerophilic fraction of that microflora. The organs enlarge only after alteration of the anaerobic fraction as well. As previous findings have indicated $(6,10)$ elements of the anaerobic microflora in adult mice may play a role in maintaining normal cecal size. Therefore, alteration of the anaerobic microflora is probably the key element in enlargement of the ceca in neonatal mice.

In this regard, it is important to stress that only alteration and not complete destruction of the microflora is necessary for the ceca to enlarge (10). Many of the enlarging organs contain an extensive abnormal microbial flora including enormous populations of anaerobic microorganisms. Large populations of coliforms, enterococci, clostridia, and unusual nonsporeforming gram-negative bacteria can be found in the ceca of the mice treated with penicillin. In contrast, only small populations of coliforms and enterococci, large populations of lactobacilli and bacteroides, and enormous populations of gram-negative fusiform-shaped bacteria can be found in the ceca of the untreated mice (11, 13).

In these untreated animals the fusiform-shaped anaerobes colonize in layers the mucin on the epithelium of the cecum and colon during the third week after birth (11). These layers do not develop in the baby mice treated with penicillin. Similarly, these particular microbial layers disappear from the ceca of mice treated as adults with penicillin and other antibacterial drugs (10). 
They do not reappear in such animals given the drug for a sustained period even though the ceca may be colonized thereafter by enormous microbial populations. Therefore, the gramnegative oxygen-intolerant fusiform-shaped bacteria that form the layers on the bowel epithelium seem certainly to be involved in maintaining normal cecal size (10).

The mechanism of such a physiological interaction remains obscure. The microorganisms may act to enhance motility of the bowel by destroying a substance that induces relaxation of smooth muscle (4). They may act as well to influence the water transport mechanisms of the cecal mucosa $(6,10)$. We believe that studies of these problems should include careful examination of the roles of the oxygen-intolerant anaerobic bacteria.

\section{ACKNOWLEDGMENTS}

This investigation was supported by Public Health Service research grant AI-08254 from the National Institute of Allergy and Infectious Diseases. The work with NCS-D mice was accomplished while the senior author was a Guest Investigator with Réne Dubos at the Rockefeller University in New York, N.Y.

\section{LITERATURE GITED}

1. Dubos, R. J., and R. W. Schaedler. 1960. The effect of the intestinal flora on the growth rate of mice and on their susceptibility to experimental infections. J. Exp. Med. 111: 407-417.
2. Dubos, R., R. W. Schaedler and M. Stephens. 1963. The effect of antibacterial drugs on the fecal flora of mice. J. Exp. Med. 117:231-243.

3. Dubos, R., R. W. Schaedler, and R. Costello. 1963. The effect of antibacterial drugs on the body weight of mice. J. Exp. Med. 117:245-254.

4. Gordon, H. A. 1965. Demonstration of a bioactive substance in caecal contents of germfree animals. Nature (London) 205:571-572.

5. Lee, A., J. Gordon, and R. Dubos. 1968. Enumeration of the oxygen sensitive bacteria usually present in the intestines of healthy mice. Nature (London) 220:1137-1139.

6. Loeschke, K., and H. A. Gordon. 1970. Water movement across the cecal wall of the germfree rat. Proc. Soc. Exp. Biol. Med. 133:1217-1222.

7. Meynell, G. G. 1963. Antibacterial mechanisms of the mouse gut. II. The role of Eh and volatile fatty acids in the normal gut. Brit. J. Exp. Pathol. 44:209-219.

8. Mushin, R., and R. Dubos. 1965. Colonization of the mouse intestine with Escherichia coli. J. Exp. Med. 122:745-757.

9. Omata, R. R., and M. N. Disraely. 1956. A selective medium for oral fusobacteria. J. Bacteriol. 72:677-680.

10. Savage, D. C., and R. Dubos. 1968. Alterations in the mouse cecum and its flora produced by antibacterial drugs. J. Exp. Med. 128:97-110.

11. Savage, D. C., R. Dubos, and R. W. Schaedler. 1967. The gastrointestinal epithelium and its autochthonous bacterial flora. J. Exp. Med. 127:67-76.

12. Schaedler, R. W., and R. J. Dubos. 1962 The fecal flora of various strains of mice. Its bearing on their susceptibility to endotoxin. J. Exp. Med. 115:1149-1160.

13. Schaedler, R. W., R. Dubos, and R. Costello. 1965. The development of the bacterial flora in the gastrointestinal tract of mice. J. Exp. Med. 122:59-66. 